\title{
Regioregular Copolymers of 3-Alkoxythiophene and Their Photovoltaic
}

\section{Application}

\author{
Chenjun Shi, Yan Yao, Yang Yang, Qibing Pei \\ Department of Materials Science and Engineering, The Henry Samueli School of Engineering \\ and Applied Science, University of California, Los Angeles, CA 90095-1595
}

\section{Measurement and Characterization}

${ }^{1} \mathrm{H}$ and ${ }^{13} \mathrm{C}$ NMR spectra were recorded on Varian Inova 500 or Bruker DRX 400 in deuterated chloroform solution. Number-average $(M n)$ and weight-average $(M w)$ molecular weights were determined by a gel permeation chromatography (GPC) using a Varian Prostar Solvent Dilvery Module 230, UV-Vis detector 340. Samples were filtered through a $0.2 \mu \mathrm{m}$ PTFE filter membrane prior to injection. Three $300 \mathrm{~mm}$ Waters Stryragel HR columns were calibrated with polystyrene standards using THF as the eluent with a flow rate of $1.0 \mathrm{~mL} / \mathrm{min}$. The elemental analysis was performed on Vario EL elemental analysis instrument (ELEMENTAR Co.). UV-vis absorption spectra were recorded on a Varian Cary 50 spectrophotometer.

\section{Synthetic Procedures for Monomers and Polymers}

All procedures involving air-sensitive reagents were performed under an atmosphere of dry argon. 9,9-Dioctylfluorene-2,7-bis(trimethyleneborate) (DOF), THF (anhydrous), DMF (anhydrous), 3-Bromothiophene, 1-Decanol, and $\mathrm{Ni}(\mathrm{dppp}) \mathrm{Cl}_{2}$ etc. were purchased from Aldrich and were used without further purification. 3-Octylthiophene, 2,5-dibromo-3-octlythiophene and 
4,7-dibromo-2,1,3-benzothiadiazole were prepared according to the published procedures and have been described elsewhere.$^{1,2,3}$

3-Decyloxythiophene was synthesized following the procedure in Ref. [4] with modification. 1Decanol $(0.51 \mathrm{~mol}, 80.27 \mathrm{~g})$ was added dropwise to $3.5 \mathrm{~g}(0.15 \mathrm{~mol})$ of sodium metal. After complete disappearance of sodium, the residual alcohol was removed in vacuum and the remaining solid was dissolved in $20 \sim 30 \mathrm{ml}$ DMF. After the solution was heated to $110{ }^{\circ} \mathrm{C}, 12.2 \mathrm{~g}$ (0.075 mol) of 3-bromo-thiophene and $1.0 \mathrm{~g}(0.00053 \mathrm{~mol})$ of copper (I) iodide were added. After $16 \mathrm{hrs}$ of stirring at $110{ }^{\circ} \mathrm{C}$, the mixture was poured into water and extracted with ether three times. The filtrate was concentrated in vacuo and the yellow oily residue was chromatographed on a silica column using hexane as the eluent to yield $15.5 \mathrm{~g}$ of yellow liquid (86\% yield). Element Anal. Calcd for $\mathrm{C}_{14} \mathrm{H}_{24} \mathrm{SO}$ : C, 69.94; H, 10.06; O, 6.66; S, 13.34, Found: C, 69.90; H, 10.00; O, 6.64; S, 13.30

${ }^{1} \mathrm{H}-\mathrm{NMR}: \delta=7.17(\mathrm{~d}, 1 \mathrm{H}), 6.77(\mathrm{~d}, 1 \mathrm{H}), 6.23(\mathrm{~d}, 1 \mathrm{H}), 3.96\left(\mathrm{t}, 2 \mathrm{H},-\mathrm{OCH}_{2}\right), 1.75(2 \mathrm{H}, \beta-\mathrm{H})$ $1.45 \sim 1.27\left(\mathrm{~m}, 14 \mathrm{H}, 7 \mathrm{CH}_{2}\right), 0.9\left(\mathrm{t}, 3 \mathrm{H},-\mathrm{CH}_{3}\right)$

${ }^{13}$ C-NMR: $\delta=129.10,124.51,119.55,96.94,70.29,31.91,29.67,29.64,29.60,29.58,29.36$, $26.06,22.70,14.13$

2-Bromo-3-decyloxythiophene (5) ${ }^{5}$ : 3-decyloxy-thiophene $(5.50 \mathrm{~g}, 0.023 \mathrm{~mol})$ was dissolved in $\mathrm{CHCl}_{3}(50 \mathrm{~mL})$ under argon atmosphere. $N$-Bromosuccinimide (NBS) (4.09 g, 0.023 mol) was added to the solution as one portion. The mixture was reacted under argon and protected from light for $4 \sim 8$ hours at room temperature $\left(25^{\circ} \mathrm{C}\right)$. Afterwards it was distilled to remove $\mathrm{CHCl}_{3}$, allowed to cool to room temperature, and diluted with hexane $(100 \mathrm{~mL})$. The mixture was filtered and the filtrate was concentrated in vacuum. The residue was applied to silica gel, eluted with 1:9 ethyl acetate/hexane to give $6.97 \mathrm{~g}$ (94\% yield) of light yellow liquid. Element Anal. 
Calcd. for $\mathrm{C}_{14} \mathrm{H}_{23}$ BrOS: C, 52.66; H, 7.26; Br, 25.02; O, 5.01; S, 10.04. Found: C, 52.62; H, 7.25; Br, 24.90; O, 5.09; S, 10.04.

${ }^{1} \mathrm{H}-\mathrm{NMR}\left(\mathrm{CDCl}_{3}\right): \delta=7.16(\mathrm{~d}, 1 \mathrm{H}), 6.75(\mathrm{~d}, 1 \mathrm{H}), 4.01\left(\mathrm{t}, 2 \mathrm{H},-\mathrm{OCH}_{2}\right), 1.75(2 \mathrm{H}, \beta-\mathrm{H}) 1.45 \sim 1.27$ $\left(\mathrm{m}, 14 \mathrm{H}, 7 \mathrm{CH}_{2}\right), 0.9\left(\mathrm{t}, 3 \mathrm{H},-\mathrm{CH}_{3}\right)$

${ }^{13} \mathrm{C}-\mathrm{NMR}: \delta=129.10,124.12,117.53,91.60,72.27,31.91,29.57,29.56,29.49,29.35,29.33$, $25.83,22.70,14.14$

2,5-Dibromo-3-decyloxythiophene ${ }^{5}$ : $N$-Bromosuccinimide (NBS) (3.75 g, $\left.0.021 \mathrm{~mol}\right)$ was added to a solution of 3-decoxy-thiophene $(2.53 \mathrm{~g}, 0.0105 \mathrm{~mol})$ in $\mathrm{CCl}_{4}(30 \mathrm{~mL})$ as one portion. The resulting dark solution was stirred at room temperature for 16 hours under argon and protected from light. Then it was distilled to remove solvent, allowed to cool to room temperature and diluted with hexane $(100 \mathrm{~mL})$. The mixture was filtered. The filtrate was concentrated in vacuo and the yellow oily residue was chromatographed on a silica column using hexane as the eluent to give $3.38 \mathrm{~g}$ of light yellow liquid (83\% yield). Element Anal. Calcd. for $\mathrm{C}_{14} \mathrm{H}_{22} \mathrm{Br}_{2} \mathrm{OS}: \mathrm{C}, 42.23 ; \mathrm{H}, 5.57 ; \mathrm{Br}, 40.13 ; \mathrm{O}, 4.02 ; \mathrm{S}, 8.05$. Found: C, 42.20; H, 5.60; Br, 40.0; $\mathrm{O}, 4.00 ; \mathrm{S}, 8.10$.

${ }^{1} \mathrm{H}-\mathrm{NMR}: \delta=6.77(\mathrm{~s}, 1 \mathrm{H}), 3.99\left(\mathrm{t}, 2 \mathrm{H},-\mathrm{OCH}_{2}\right), 1.75(2 \mathrm{H}, \beta-\mathrm{H}) 1.45 \sim 1.27\left(\mathrm{~m}, 14 \mathrm{H}, 7 \mathrm{CH}_{2}\right), 0.9(\mathrm{t}$, $\left.3 \mathrm{H},-\mathrm{CH}_{3}\right)$

${ }^{13} \mathrm{C}-\mathrm{NMR}: \delta=154.57,121.12,110.53,90.90,71.30,31.92,29.58,29.56,29.50,29.36,29.33$, $25.87,22.72,14.12$

4,7-Bis-(3-decyloxy-thiophen-2-yl)-2,1,3-benzothiadiazole (6) (DTB): A solution of 2-bromo3-decyloxythiophene $(2.5 \mathrm{~g}, 7.8 \mathrm{mmol})$ in $10 \mathrm{~mL}$ THF was added slowly over 5 minutes to a stirred suspension of magnesium $(0.28 \mathrm{~g}, 12 \mathrm{mmol})$ in $5 \mathrm{ml}$ THF at argon atmosphere. The mixture was stirred at $50{ }^{\circ} \mathrm{C} 3$ hours and cooled down. The clear solution was added into a mixture of 4,7-dibromo-2,1,3-benzothiadiazole $(0.69 \mathrm{~g}, 2.37 \mathrm{mmol})$ and $\mathrm{Ni}(\mathrm{dppp})_{2} \mathrm{Cl}_{2}(42 \mathrm{mg}$, 
$0.078 \mathrm{mmol}$ ) in $20 \mathrm{ml}$ THF under an inert atmosphere (Ar) and was refluxed for 18 hours. After the reaction completed, the mixture was poured into water and extracted by ether. The organic layer was washed by $\mathrm{Na}_{2} \mathrm{CO}_{3}$ and $\mathrm{NaCl}$ aqueous solutions, respectively, and dried with $\mathrm{MgSO}_{4}$. After removal of the solvent (ether), the residue was applied onto a silica gel column and eluted with 2:8 $\mathrm{CH}_{2} \mathrm{Cl}_{2} /$ hexane $0.796 \mathrm{~g}$ of red solid (55\%). Element Anal. Calcd for $\mathrm{C}_{34} \mathrm{H}_{48} \mathrm{~N}_{2} \mathrm{O}_{2} \mathrm{~S}_{3}: \mathrm{C}$, 66.62; H, 7.89; N, 4.57; O, 5.22; S, 15.69. Found: C, 66.58; H, 7.70; N, 4.60; O, 5.12; S, 15.70.

${ }^{1} \mathrm{H}-\mathrm{NMR}: \delta=8.457\left(\mathrm{~S}, 2 \mathrm{H}\right.$, benzo), $7.44(\mathrm{~d}, 2 \mathrm{H}, 5-\mathrm{TH}), 6.99(\mathrm{~d}, 2 \mathrm{H}, 4-\mathrm{TH}), 4.15\left(\mathrm{t}, 4 \mathrm{H},-\mathrm{OCH}_{2}\right)$, $1.82(4 \mathrm{H}, \beta-\mathrm{H}), 1.45 \sim 1.27\left(\mathrm{~m}, 28 \mathrm{H}, 14 \mathrm{CH}_{2}\right), 0.9\left(\mathrm{t}, 6 \mathrm{H},-\mathrm{CH}_{3}\right)$

${ }^{13} \mathrm{C}-\mathrm{NMR}: \delta=153.64,151.21,126.73,123.45,125.30,120.78,115.27,72.12,31.92,29.63$, $29.59,29.51,29.35,29.31,26.06,22.72,14.13$

4,7-Bis-(5-bromo-3-decyloxy-thiophen-2-yl)-2,1,3-benzothiadiazole (7): $N$-Bromosuccinimide (NBS) $(0.528 \mathrm{~g}, 2.86 \mathrm{mmol})$ was added to a solution of 4,7-Bis-(3-decyloxy-thiophen-2-yl)2,1,3-benzothiadiazole $(0.795 \mathrm{~g}, 1.3 \mathrm{mmol})$ in THF $(20 \mathrm{~mL})$. The resulting dark red solution was stirred at room temperature for 16 hours under argon atmosphere and protected from light. Then it was distilled to remove solvent, allowed to cool to room temperature, and diluted with hexane $(100 \mathrm{~mL})$. The mixture was filtered and the filtrate was concentrated in vacuo. After removal of the solvent (hexane), the residue was applied onto a silica gel column and eluted with 2:8 $\mathrm{CH}_{2} \mathrm{Cl}_{2}$ hexane to give $0.456 \mathrm{~g}$ dark red solid $(83 \%$ yield). Element Anal. Calcd. for $\mathrm{C}_{34} \mathrm{H}_{46} \mathrm{Br}_{2} \mathrm{~N}_{2} \mathrm{O}_{2} \mathrm{~S}_{3}: \mathrm{C}, 52.98 ; \mathrm{H}, 6.02 ; \mathrm{Br}, 20.73 ; \mathrm{N}, 3.63 ; \mathrm{O}, 4.15 ; \mathrm{S}, 12.48$. Found: $\mathrm{C}, 53.00 ; \mathrm{H}$, $6.01 ; \mathrm{Br}, 20.67 ; \mathrm{N}, 3.60 ; \mathrm{O}, 4.18 ; \mathrm{S}, 12.50$.

${ }^{1} \mathrm{H}-\mathrm{NMR}: \delta=8.34(\mathrm{~s}, 2 \mathrm{H}), 6.98(\mathrm{~s}, 2 \mathrm{H}), 4.13\left(\mathrm{~s}, 4 \mathrm{H}, 2 \mathrm{OCH}_{2}\right), 1.84(4 \mathrm{H}, \beta-\mathrm{H}), 1.48 \sim 1.29(28 \mathrm{H}$, $\left.7 \mathrm{CH}_{2}\right), 0.9\left(\mathrm{t}, 6 \mathrm{H}, 2 \mathrm{CH}_{3}\right)$

${ }^{13}$ C-NMR: $\delta=154.64,152.21,126.73,123.45,119.78,117.74,114.27,72.10,31.91,29.61$, $29.58,29.50,29.35,29.31,26.06,22.70,14.12$ 
Poly(3-decyloxythiophene-2,5-diyl)s (P3DOT) ${ }^{6,7}$ : 2,5 -dibromo-3-decoxy-thiophene (1.23 g, $3.12 \mathrm{mmol}$ ) (1) was dissolved in $18 \mathrm{~mL}$ of dry THF. Methylmagnesium bromide (2.25 mL, $1.4 \mathrm{M}$ solution in toluene/THF) was added and the mixture was heated to reflux for 1 hour. Afterwards $\mathrm{Ni}(\mathrm{dppp}) \mathrm{Cl}_{2}(16.9 \mathrm{mg})$ was added and the solution was stirred at reflux for $2 \mathrm{~h}$. The mixture was poured into $150 \mathrm{~mL}$ of methanol and filtered. The solid was re-dissolved in chlorobenzene, filtered, and then precipitated with a mixture of acetone and methanol. The solid was collected by filtration and drying in vacuo to afford $0.510 \mathrm{~g}$ ( $65 \%$ yield) of the title polymer as a dark blue powder.

Poly(3-octylthiophene-2,5-diyl-co-3-decyloxythiophene-2,5-diyl)s (POT-co-DOT) ${ }^{6,}{ }^{7}:$ 2,5dibromo-3-decoxythiophene $(0.760 \mathrm{~g}, 2 \mathrm{mmol})$ and 2,5 dibromo-3-octylthiophene $(0.708 \mathrm{~g}, 2$ mmol) was dissolved in $25 \mathrm{~mL}$ of dry THF. Methylmagnesium bromide $(2.85 \mathrm{~mL}, 1.4 \mathrm{M}$ solution in toluene/THF) was added and the mixture was heated to reflux for $1 \mathrm{~h}$. $\mathrm{Ni}(\mathrm{dppp}) \mathrm{Cl}_{2}$ $(19 \mathrm{mg})$ was added and the solution was stirred at reflux for $6 \mathrm{~h}$. The mixture was poured into $150 \mathrm{~mL}$ of methanol and filtered. The solid was re-dissolved in chlorobenzene and filtered then deposited with acetone/methanol. The solid was collected by filtration and drying in vacuo to afford $0.710 \mathrm{~g}(65 \%$ yield $)$ of the title polymer as a dark blue powder.

\section{Poly\{(9,9-dioctylfluorene)-2,7-diyl-alt-[4,7-bis(3-decyloxythien-2-yl)-2,1,3-}

benzothiadiazole]-5',5"-diyl\} (PF-co-DTB). The mixture of 9,9-Dioctylfluorene-2,7bis(trimethyleneborate) (204 mg, $0.36 \mathrm{mmol}), 4,7-B i s-(5-b r o m o-3-d e c y l o x y-t h i o p h e n-2-y l)-$ 2,1,3-benzothiadiazole (280 $\mathrm{mg}, 0.36 \mathrm{mmol})$, toluene $(15 \mathrm{~mL})$, phase transfer agent, Aliquat 336.RTM (52 mg), tetrakis(triphenylphosphine)palladium(0) (4.2 mg,), and 2M aqueous sodium carbonate solution $(4.5 \mathrm{~mL})$ were degassed and stirred at $110{ }^{\circ} \mathrm{C}$ for 12 hours. To terminate the polymerization, $0.1 \mathrm{~g}$ of benzene boronic acid (dissolved in $1 \mathrm{~mL}$ THF) and the reaction was allowed to continue for 2 more hours then add $2 \mathrm{ml}$ bromobenzene to react 3 hours. After 
cooling, the mixture was diluted with toluene and transferred to a separatory funnel. The aqueous phase was removed and the organic phase was washed with water. The mixture was precipitated from methanol. The solid was collected by filtration and dried in vacuo to yield $0.35 \mathrm{~g}(98 \%$ yield) of the title polymer as a dark red powder.

\section{Electrochemical Cyclic Voltammetry}

Using a CHI660A electrochemical workstation, cyclic voltammetry was carried out in a 0.1M tetrabutylammonium tertrafluoroborate $\left(\mathrm{Bu}_{4} \mathrm{~N} \cdot \mathrm{BF}_{4}\right)$ solution in acetonitrile $\left(\mathrm{CH}_{3} \mathrm{CN}\right)$. The working electrode was a Pt disk $\left(0.2 \mathrm{~cm}^{2}\right)$, the counter electrode was a Pt wire, and the reference electrode was a saturated calomel electrode. The electrochemical potential was calibrated against $\mathrm{Fc} / \mathrm{Fc}^{+}$

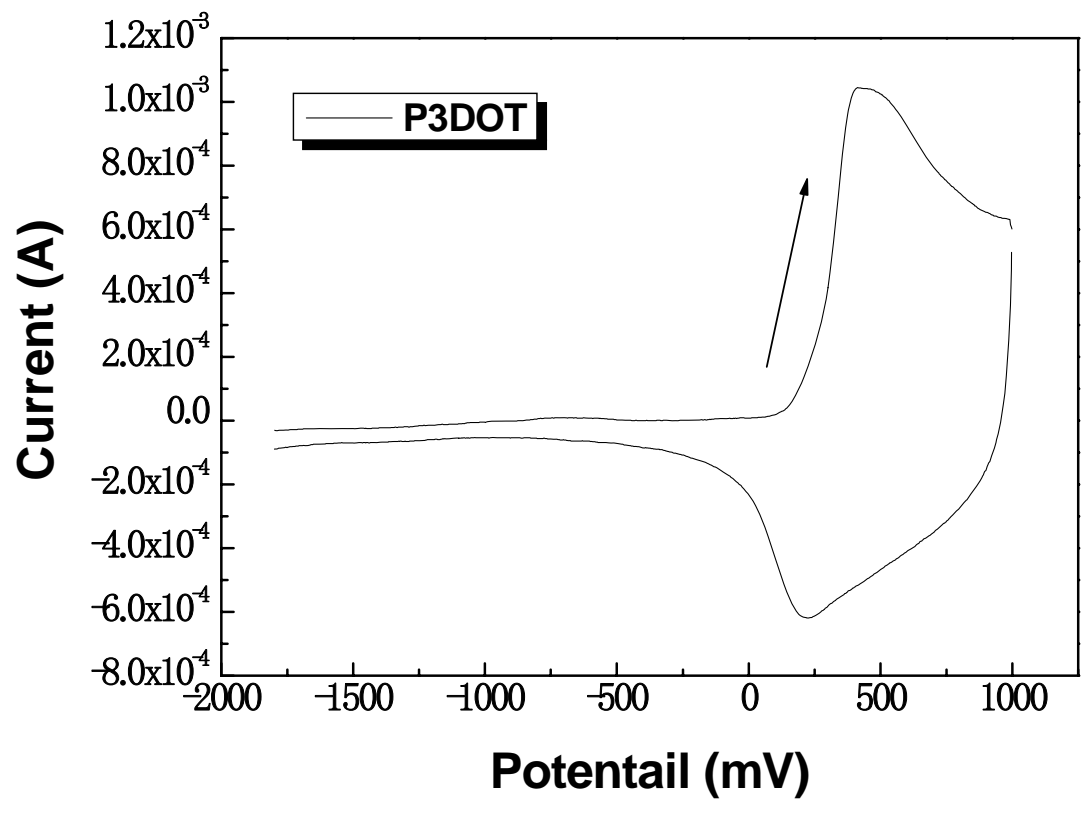



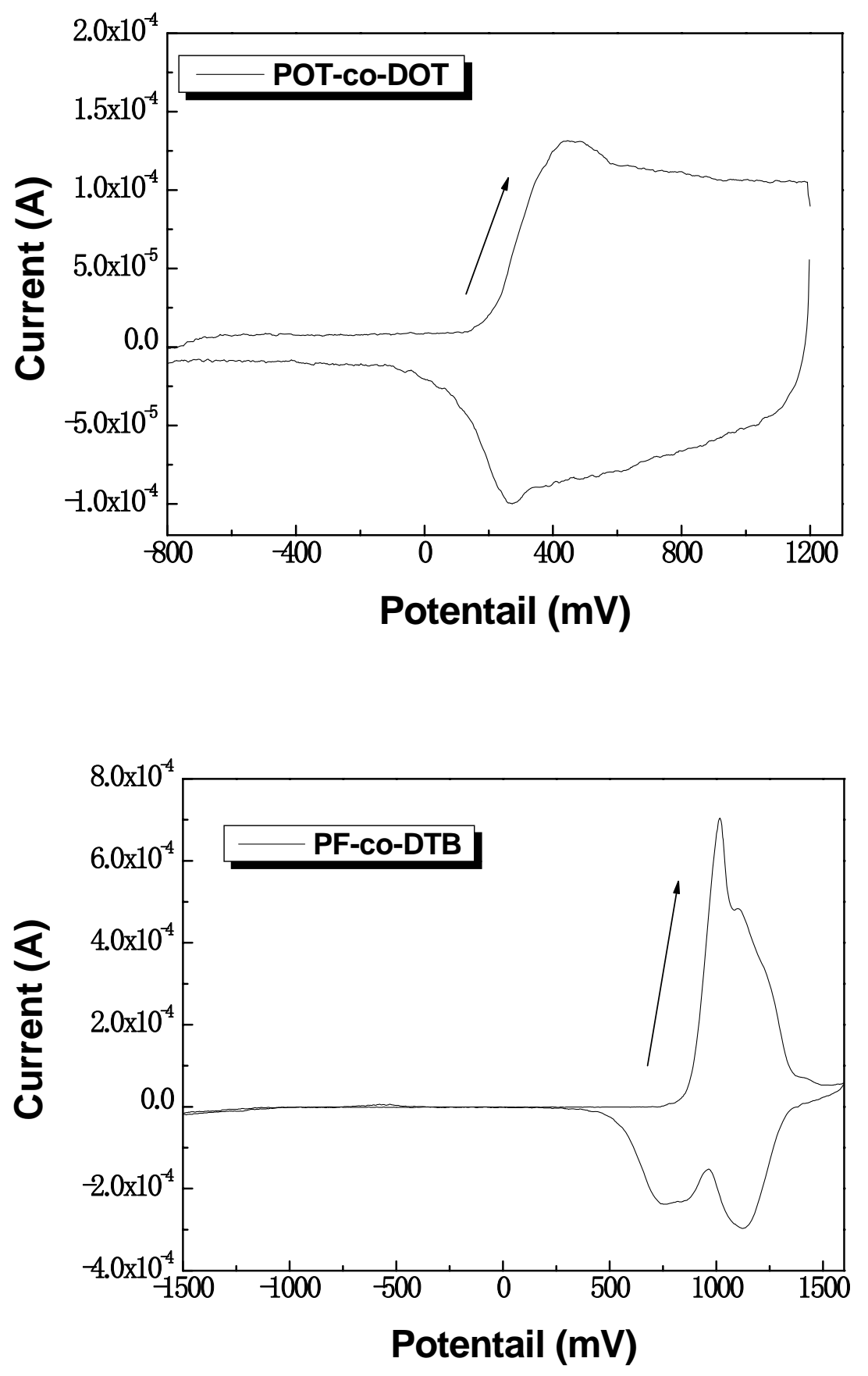

Figure S1. Cyclic voltammograms of P3DOT, POT-co-DOT and PF-co-DTB films in monomer free electrolyte solution of $0.1 \mathrm{M} \mathrm{Bu}_{4} \mathrm{~N} \cdot \mathrm{BF}_{4}$ in $\mathrm{CH}_{3} \mathrm{CN}$ at a scan rate of $100 \mathrm{mV} / \mathrm{s}$ 


\section{Photovoltaic Device Fabrication and Characterization}

The polymer photovoltaic devices consisted of a thin film of a polymer blend (P3DOT, POT-coDOT, PF-co-DTB with PCBM), sandwiched in-between a transparent anode (indium tin-oxide, ITO) and a metal cathode. Before device fabrication, the glass substrates coated with ITO ( 150 $\mathrm{nm}$ ) were cleaned sequentially by ultrasonic treatment in detergent, de-ionized water, acetone, isopropyl alcohol, and UV-Ozone treatment for 20 minutes. Poly(3,4ethylenedioxythiophene)/poly(styrenesulfonate) (PEDOT:PSS) layer of about $25 \mathrm{~nm}$ thick was spin-coated from an aqueous solution (Baytron P VP A1 4083) onto ITO coated glass substrates, followed by baking at $120^{\circ} \mathrm{C}$ for 1 hour. The polymer/PCBM solution in chlorobenzene (CB) was prepared at various Polymer/PCBM weight ratios (Table 3). The mixture solution was then stirred for $\sim 12$ hours at $40^{\circ} \mathrm{C}$ in a glove box and was spin-coated on top of the PEDOT:PSS layer. The thickness of the polymer/PCBM blend layers were in the range of 80 to $100 \mathrm{~nm}$. To complete the device fabrication, $\sim 1 \mathrm{~nm}$ thickness of lithium fluoride (LiF) and $80 \mathrm{~nm}$ thickness of aluminum (cathode) were successively deposited thermally under vacuum of $\sim 10^{-6}$ Torr. The active area of the device was approximately $0.11 \mathrm{~cm}^{2}$. The current-voltage $(I-V)$ curves were obtained by a Keithley 2400 source-measure unit. The photocurrent was measured under simulated AM1.5G irradiation $\left(100 \mathrm{~mW} / \mathrm{cm}^{2}\right)$ using a xenon lamp based solar simulator (Oriel $96000150 \mathrm{~W}$ Solar Simulator). The thicknesses of the various films were measured using Dektak profilometer. All devices were fabricated and tested in oxygen and moisture free nitrogen environment inside a glove-box $\left(<0.1 \mathrm{ppm}_{2} \& \mathrm{H}_{2} \mathrm{O}\right)$. 


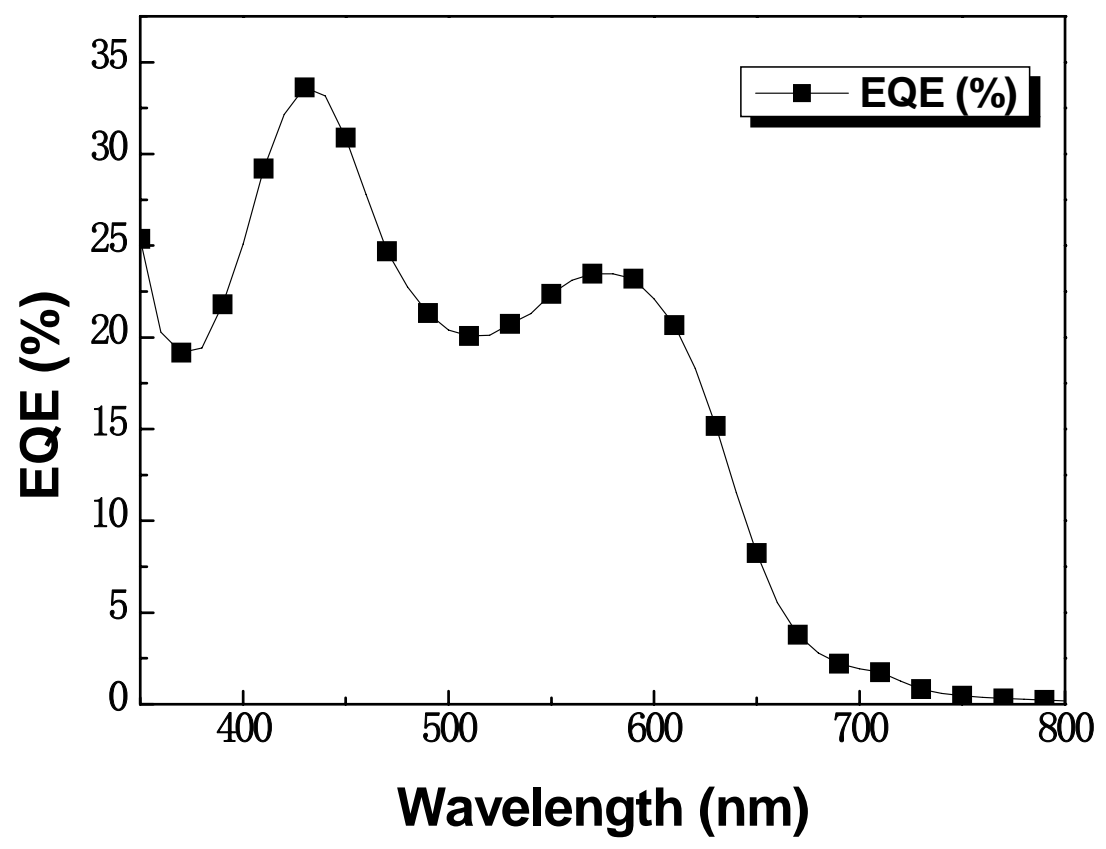

Figure S2. IPCE plot of the PF-co-DTB /PCBM (1:4) bulk heterojunction solar cells 

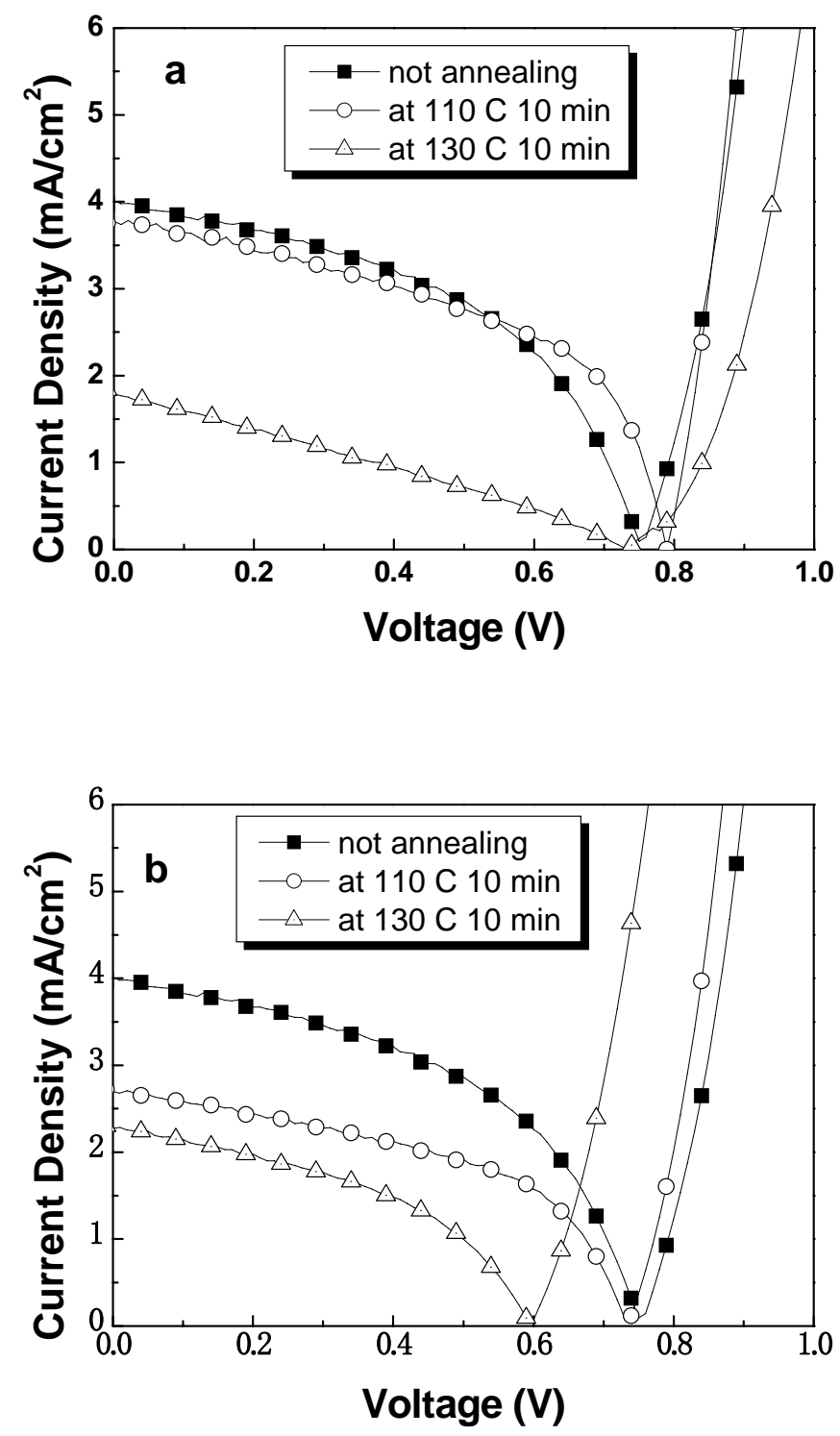

Figure S4. Current-voltage characteristics of PF-co-DTB /PCBM (1:4) bulk heterojunction solar cells under white light illumination (AM 1.5 conditions) (a): annealed at different temperature before deposition of the top electrode, (b) annealed at different temperature after deposition of the top electrode. 


\section{References}

[1] McCullough, R. D.; Lowe, R. D.; Jayaraman, M.; Anderson, D. L.; J Org Chem 1993, 58, 904.

[2] Chen, T-A.; Wu, X.; Rieke. RD.; J Am Chem Soc 1995, 117, 233

[3] Pilgram, K.; Zupan, M.; Skile, R.; J. Heterocycl. Chem. 1970, 6, 629

[4] Keegstra, M. A.; Peters, T. H. A.; Brandsma, L. Tetrahedron 1992, 48, 3633.

[5] Loewe, R. S.; Ewbank, P. C.; Liu, J.; Zhai, L.; McCullough, R. D. Macromolecules 2001, 34, 4324.

[6] Sheina, E. E.; Khersonsky, S. M.; Jones, E. G.; McCullough, R. D.; Chem. Mater.; 2005; 17; 3317.

[7] (a) Loewe, R. S.; Khersonsky, S. K.; McCullough, R. D.; Adv. Mater. 1999, 3, 250 (b) Loewe, R. S.; McCullough, R. D.; Polym. Prepr. 1999, 40 (2), 852 (c), 